\title{
Preface: New challenges in anostracan research, a tribute to Graziella Mura
}

\author{
Federico Marrone (id - D. Christopher Rogers (id) Paola Zarattini • \\ Luigi Naselli-Flores (i)
}

Published online: 6 September 2017

(C) Springer International Publishing AG 2017

This special volume of Hydrobiologia is dedicated to the memory of Graziella Mura, who unexpectedly passed away on 23 March 2016 when she was still carrying out her highly influential and worldrenowned research on Anostraca. She provided outstanding contributions to the current knowledge of the taxonomy and ecology of this distinctive crustacean group over the last 45 years. This volume is a tribute to her and her role in anostracan research by the community of anostracan specialists.

Electronic supplementary material The online version of this article (doi:10.1007/s10750-017-3355-4) contains supplementary material, which is available to authorized users.

Guest editors: Federico Marrone, D. Christopher Rogers, Paola Zarattini \& Luigi Naselli-Flores / New Challenges in Anostracan Research: a Tribute to Graziella Mura

\section{F. Marrone}

Department of Biological, Chemical and Pharmaceutical

Sciences and Technologies - Section of Zoology,

University of Palermo, via Archirafi 18, 90123 Palermo,

Italy

e-mail: federico.marrone@unipa.it

D. C. Rogers

Kansas Biological Survey and the Natural History Museum (Biodiversity Institute), Kansas University, Higuchi Hall, 2101 Constant Avenue, Lawrence, KS 66047-3759, USA

e-mail: branchiopod@gmail.com
Graziella Mura was born in Milan (Italy) on 7 December 1940. She graduated from the University of Rome "La Sapienza" (Italy), where she later became Professor of Zoology. There, she passionately devoted herself to teaching and research. She established the "Laboratory of Applied Zoology" at the University of Rome, offering many students the opportunity to train and make their first research experiences, and promoting and supervising countless Master and $\mathrm{PhD}$ theses.

Her research interests from the first focused on inland water crustaceans, especially the anostracans. She co-authored her first publication on Anostraca in 1972 (Cottarelli \& Mura, 1972), and more than 1 year after her death, papers with her co-authorship are still being published, demonstrating her dynamic research activities until the very last days of her life (e.g. Cottarelli et al., 2017; Kappas et al., 2017; Zarattini et al., 2017). The last paper she co-authored before she

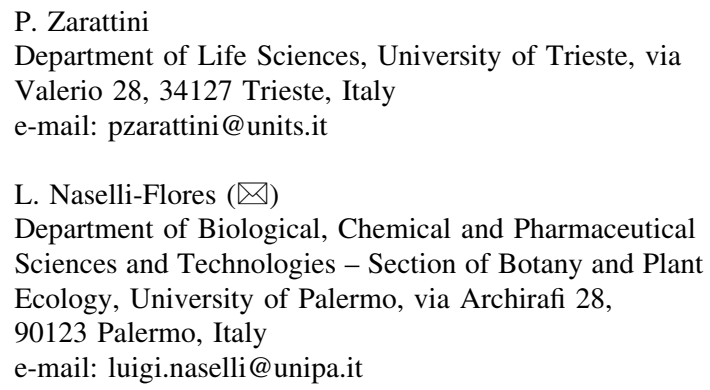




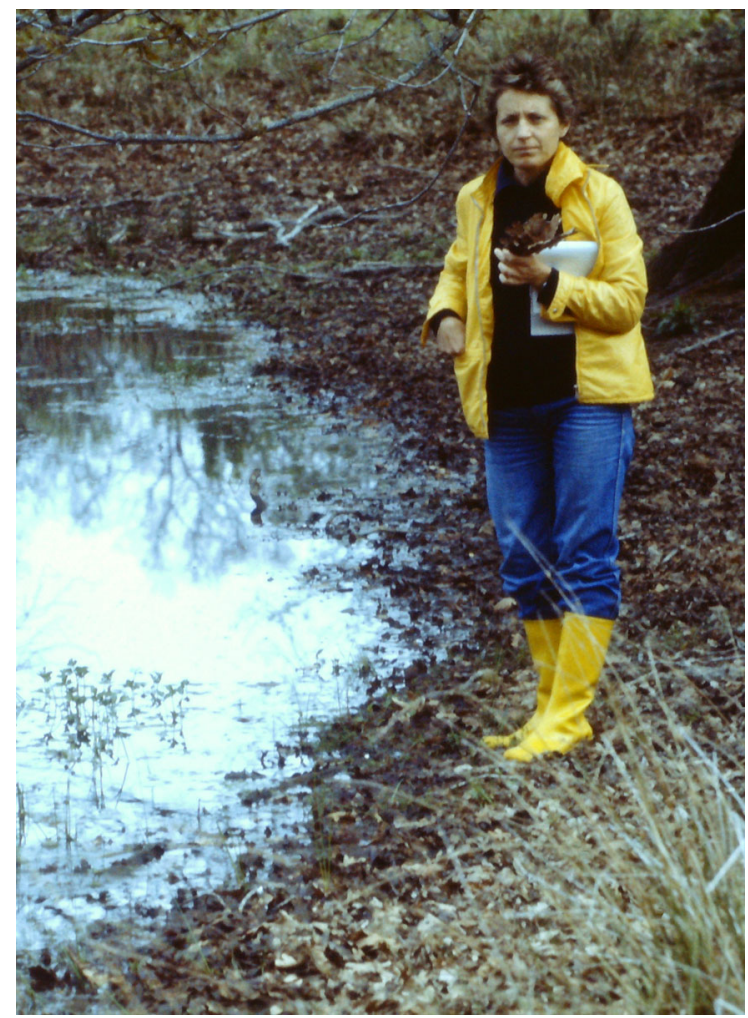

April 1983. Professor Graziella Mura sampling in the temporary pond "T19" of the Castelporziano Presidential Estate (Rome, Italy), where Chirocephalus diaphanus and Chirocephalus kerkyrensis co-occur (see Mura \& Cottarelli, 1984)

passed away concerns the protection of the Iberian endemic Linderiella baetica Alonso \& Garcia-deLomas, 2009, demonstrating her personal commitment to the protection of this group of crustaceans (Garcia de Lomas et al., 2016).

In more than four decades of activity, Graziella Mura described six anostracan species (Cottarelli \& Mura, 1975, 1984; Cottarelli et al., 2007, 2010), and produced pioneer works on anostracan taxonomy, ecology and faunistics. In particular, she increased our knowledge on the importance and significance of anostracan egg morphology (e.g. Mura et al., 1978; Mura, 1986; Mura, 1991, 1992a; Bruner et al., 2013), investigated anostracan use in aquaculture (e.g. Mura, 1992b, 1995; Mura et al., 1997, 1999; Mura \& Fancello, 2005), contributed to the knowledge of
Palearctic anostracan biodiversity and taxonomy (e.g. Nagorskaya et al., 1998; Mura, 1999, 2001; Brtek \& Mura, 2000; Mura \& Azari Takami, 2000; Mura \& Nagorskaya, 2005; Mura et al., 2011), with a special focus on the genus Artemia Leach, 1819 (e.g. Mura et al., 1989a, 1989b; Mura, 1990; Mura \& Brecciaroli, 2004; Mura et al., 2005, 2006; Amat et al., 2007; Gajardo \& Mura, 2011), and produced innovative works on the molecular systematics and phylogeography of the group (e.g. Ketmaier et al., 2003, 2005, 2008, 2012; Zarattini et al., 2013). Dormancy in Anostraca was one of the main topics of her research, and she contributed to understand the mechanisms allowing the hatching of diapause eggs by investigating the underlying genetic, epigenetic and environmental causes (e.g. Mura \& Zarattini, 1999; Zarattini et al., 2002; Maffei et al., 2005). She also compiled the first comprehensive monograph on the Italian anostracan fauna (Cottarelli \& Mura, 1983), which is still a standard reference in the westPalearctic. This resulted in her appointment as coordinator for the "large branchiopod" group (Branchiopoda: Anostraca, Notostraca, Spinicaudata) for the "Checklist of the Italian fauna" (Cottarelli et al., 1995) and "CkMap" (Mura, 2005) projects. She was among the members of the editorial board of Journal of Biological Research-Thessaloniki since the beginning of its publication and actively contributed to the journal management until the very end. A nonexhaustive list of relevant papers published by Graziella Mura is presented in Table S1 (available as Electronic Supplementary Material).

Acknowledging her important contributions in anostracan research, two chirocephalid species were named in her honour: Chirocephalus murae Brtek \& Cottarelli, 2006 and Chirocephalus graziellae (Alonso \& Naganawa, 2008), the latter originally described as "Galaziella murae" (see discussion in Rogers, 2013).

She assembled a rich reference collection during her career, which was generously donated along with her reprint collection to one of the guest editors of this special volume (FM). Both the specimens and the reprint collection are currently deposited in the University of Palermo (Italy) and are being reorganised and catalogued in order to make them publicly available. 
More than 90 authors from 25 countries and five continents offered 26 manuscripts for this special volume, of which 14 were selected for inclusion. It is worth stressing that the papers included in this special volume are authored by up to 22 co-authors (average: 6.3 authors/paper), often in the frame of international cooperation projects, thus demonstrating that the anostracan research community is harmonious and free from the jealousy and competition which often plague Academia. We think that this is the best way for research to progress, and we recognise the value of Graziella Mura's legacy to that end.

Finally, we wish to express our gratitude to the numerous colleagues around the world who submitted their works for this special issue. Moreover, we deeply appreciated the cooperation we received from the Hydrobiologia Editors Sidinei M. Thomaz and Koen Martens, as well as from the people working at Springer. The careful reviewing work carried out by more than 50 external referees, who promptly answered our invitations to review, prove the willingness of the whole scientific community to pay a tribute to the memory of the late Professor Graziella Mura.

\section{References}

Alonso, M. \& H. Naganawa, 2008. A new fairy shrimp Galaziella murae (Branchiopoda: Anostraca) from Mongolia. Journal of Biological Research- Thessaloniki 10: 119-128.

Amat, F., F. Hontoria, J. C. Navarro, N. Vieira \& G. Mura, 2007. Biodiversity loss in the genus Artemia in the Western Mediterranean region. Limnetica 26: 387-404.

Brtek, J. \& G. Mura, 2000. Revised key to families and genera of the Anostraca with notes on their geographical distribution. Crustaceana 73: 1037-1088.

Brtek, J. \& V. Cottarelli, 2006. Chirocephalus murae, a new species (Branchiopoda, Anostraca) from Turkey. Crustaceana 79: 89-98.

Bruner, E., D. Costantini \& G. Mura, 2013. Fractal analysis of the egg shell ornamentation in anostracans cysts: a quantitative approach to the morphological variations in $\mathrm{Chi}$ rocephalus ruffoi. Hydrobiologia 705: 1-8.

Cottarelli, V. \& G. Mura, 1972. Un caso di ginandromorfismo in Chirocephalus diaphanus Prévost (Crustacea, Branchiopoda). Rivista di Idrobiologia 65: 225-230.

Cottarelli, V. \& G. Mura, 1975. Una nuova specie di anostraco (Crustacea, Branchiopoda) dell'Italia peninsulare: Chirocephalus sibyllae n. sp. Bollettino di Zoologia 42: 187-196.

Cottarelli, V. \& G. Mura, 1983. Guide per il riconoscimento delle specie animali delle acque interne italiane. Anostraci,
Notostraci, Concostraci. Vol. 18. Consiglio Nazionale delle Ricerche, Verona

Cottarelli, V. \& G. Mura, 1984. Chirocephalus ruffoi n. sp. (Crustacea, Euphyllopoda, Anostraca) di acque astatiche d'alta quota dell'appennino calabro-lucano. Bollettino del Museo Civico di Storia Naturale di Verona 1: 515-523.

Cottarelli, V., F. G. Margaritora \& G. Mura, 1995. Crustacea, Branchiopoda. In: Minelli, A., S. Ruffo \& S. La Posta (eds), Checklist delle specie della fauna italiana, 26: 1-10. (Calderini, Bologna)

Cottarelli, V., G. Mura \& R. Sulhi-Ozkutuk, 2007. On two new Anostraca species (Branchiopoda) from Turkey: chirocephalus anatolicus sp. nov. and Chirocephalus cupreus sp. nov. Crustaceana 80: 455-474.

Cottarelli, V., C. Aygen \& G. Mura, 2010. Fairy shrimps from Asiatic Turkey: redescription of Chirocephalus tauricus Pesta, 1921 and descriptions of Chirocephalus algidus sp. nov. and Chirocephalus brteki sp. nov. (Crustacea, Branchiopoda, Anostraca). Zootaxa 2528: 29-52.

Cottarelli, V., G. Mura, G. Ippolito \& F. Marrone, 2017. Chirocephalus sarpedonis sp. nov. (Branchiopoda, Anostraca, Chirocephalidae) from Turkey questions the monophyly of the traditional Chirocephalus species-groups. Hydrobiologia. doi:10.1007/s10750-017-3271-7.

Gajardo, G. \& G. Mura, 2011. The highly divergent New World Artemia species (Branchiopoda, Anostraca), A. franciscana and $A$. persimilis, show subtle differences in morphological traits involved in mating. Zootaxa 2912: 37-48.

García de Lomas, J., C. M. García, F. Hortas, F. Prunier, D. Boix, J. Sala, D. León, L. Serrano, J. Prenda, J. D. Gilbert, F. J. Guerrero, F. Marrone, M. Sahuquillo, A. Camacho, C. Olmo, M. R, Miracle, C. Zamora-Muñoz, G. Mura, M. Machado, I. Sánchez, J. A. Gálvez, M. Florencio, J. L. Pérez-Bote \& M. Alonso, 2016. Linderiella baetica Alonso \& García-de-Lomas 2009 (Crustacea, Branchiopoda, Anostraca): ¿al borde de la extinción? Revista de la Sociedad Gaditana de Historia Natural 10: 15-26

Kappas, I., D. Synefiaridou, F. Marrone, G. Alfonso, M. Alonso \& T. J. Abatzopoulos, 2017. Molecular and morphological data suggest weak phylogeographic structure in the fairy shrimp Streptocephalus torvicornis (Branchiopoda, Anostraca). Hydrobiologia. doi:10.1007/s10750-017-3203-6.

Ketmaier, V., P. Zarattini, E. De Matthaeis, M. Cobolli \& G. Mura, 2003. Intra- and inter-specific relationships in the six Italian species of the fairy shrimp genus Chirocephalus: combining allozymes and mtDNA data. Journal of Zoological Systematics and Evolutionary Research 41: 276-285.

Ketmaier, V., R. Mandatori, E. De Matthaeis \& G. Mura, 2005. Molecular systematics and phylogeography in the fairy shrimp Tanymastix stagnalis based on mitochondrial DNA. Journal of Zoology 266: 401-410.

Ketmaier, V., D. Pirollo, E. De Matthaeis, R. Tiedemann \& G. Mura, 2008. Large-scale mitochondrial phylogeography in the halophilic fairy shrimp Phallocryptus spinosa (MilneEdwards, 1840) (Branchiopoda: Anostraca). Aquatic Sciences 70: 65-76.

Ketmaier, V., F. Marrone, G. Alfonso, K. Paulus, A. Wiemann, R. Tiedemann \& G. Mura, 2012. Mitochondrial DNA regionalism and historical demography in the extant 
populations of Chirocephalus kerkyrensis (Branchiopoda: Anostraca). PLoS One 7(2): e30082.

Maffei, C., D. Vagaggini, P. Zarattini \& G. Mura, 2005. The dormancy problem for Crustacea Anostraca: a rigorous model connecting hatching strategies and environmental conditions. Ecological Modelling 185: 469-481.

Mura, G., 1986. SEM morphological survey on the egg shell in the Italian anostracans (Crustacea, Branchiopoda). Hydrobiologia 134: 273-286.

Mura, G., 1990. Artemia salina (Linnaeus, 1758) from Lymington, England: frontal knob morphology by scanning electron microscopy. Journal of Crustacean Biology 10: $364-368$.

Mura, G., 1991. Additional remarks on cyst morphometrics in anostracans and its significance.Part I: egg size. Crustaceana 61: 241-252.

Mura, G., 1992a. Additional remarks on cyst morphometrics in anostracans and its significance. Part II: egg morphology. Crustaceana 63: 225-246.

Mura, G., 1992b. Preliminary testing of Anostraca from Italy for use in freshwater fish culture. Hydrobiologia 241: 185-194.

Mura, G., 1995. Biometrics and fatty acid composition of the resting eggs of Thamnocephalus platyurus (Anostraca) in view of an eventual use as fish feed. Crustaceana 68: 629-635.

Mura, G., 1999. Current status of the Anostraca of Italy. Hydrobiologia 405: 57-65.

Mura, G., 2001. Updating Anostraca (Crustacea, Branchiopoda) distribution in Italy. Journal of Limnology 60: 45-49.

Mura, G., 2005. Crustacea Branchiopoda Anostraca, Notostraca, Conchostraca. In Ruffo, S. \& F. Stoch (eds), Checklist e distribuzione della fauna italiana. Memorie del Museo Civico di Storia Naturale di Verona, 2. serie, Sezione Scienze della Vita 16: 77-78.

Mura, G. \& G. Azari Takami, 2000. A contribution to the knowledge of the anostracan fauna of Iran. Hydrobiologia 441: 117-121.

Mura, G. \& B. Brecciaroli, 2004. Use of morphological characters for species separation within the genus Artemia (Crustacea, Branchiopoda). Hydrobiologia 520: 179-188.

Mura, G. \& V. Cottarelli, 1984. Gli anostraci delle acque temporanee di Castel Porziano (Roma). Rivista di Idrobiologia 23: $165-171$.

Mura, G. \& G. Fancello, 2005. Nutritional evaluation of decapsulated cysts of five species of fairy shrimps (Branchiopoda, Anostraca) from Italy for use in larval fish rearing. Crustaceana 78: 727-737.

Mura, G. \& L. Nagorskaya, 2005. Notes on the distribution of the genus Artemia in the former USSR countries (Russia and adjacent regions). Journal of Biological ResearchThessaloniki 4: 139-150.

Mura, G. \& P. Zarattini, 1999. Influence of parental rearing conditions on cyst production and hatching of Chirocephalus ruffoi, an endemic fairy shrimp from Italy (Anostraca). Crustaceana 72: 449-465.

Mura, G., F. Accordi \& M. Rampini, 1978. Studies on the resting eggs of some freshwater fairy shrimps of the genus
Chirocephalus: biometry and scanning electron microscopic morphology (Branchiopoda, Anostraca). Crustaceana 35: 190-194.

Mura, G., L. Del Caldo \& A. Fanfani, 1989a. Sibling species of Artemia: a light and electron microscopic survey of the morphology of the frontal knobs. Part I. Journal of Crustacean Biology 9: 414-419.

Mura, G., A. Fanfani \& L. Del Caldo, 1989b. Sibling species of Artemia: a light and electron microscopic survey of the morphology of the frontal knobs.Part II. Journal of Crustacean Biology 9: 420-424.

Mura, G., F. Ferrara, M. Delise, F. Fabietti \& A. Bocca, 1997. Evaluation of the fatty acid profiles of two fairy shrimp species, Branchipus pasai Cottarelli, 1969 and Chirocephalus kerkyrensis Pesta, 1936 (Crustacea, Anostraca) fed different diets. Hydrobiologia 359: 229-235.

Mura, G., P. Zarattini, F. Fabietti, M. Delise \& A. Bocca, 1999. The effects of different diets on the fatty acid profile of the fairy shrimp Chirocephalus ruffoi Cottarelli \& Mura, 1984 (Branchiopoda, Anostraca). Crustaceana 72: 567-579.

Mura, G., A. D. Baxevanis, G. M. Lopez, F. Hontoria, I. Kappas, S. Moscatello, G. Fancello, F. Amat \& T. J. Abatzopoulos, 2005. The use of a multidisciplinary approach for the characterization of a diploid parthenogenetic Artemia population from Torre Colimena (Apulia, Italy). Journal of Plankton Research 27: 895-907.

Mura, G., I. Kappas, A. D. Baxevanis, S. Moscatello, Q. D’Amico, G. M. Lopez, F. Hontoria, F. Amat \& T. J. Abatzopoulos, 2006. Morphological and molecular data reveal the presence of the invasive Artemia franciscana in Margherita di Savoia Salterns (Italy). International Review of Hydrobiology 91: 539-554.

Mura, G., S. R. Ozkutuk, C. Aygen \& V. Cottarelli, 2011. New data on the taxonomy and distribution of anostracan fauna from Turkey. Journal of Biological Research-Thessaloniki 15: 17-23.

Nagorskaja, L., J. Brtek \& G. Mura, 1998. The Anostraca of the Republic of Belarus. Hydrobiologia 367: 21-30.

Rogers, D. C., 2013. Anostraca Catalogus (Crustacea: Branchiopoda). The Raffles Bulletin of Zoology 61: 525-546.

Zarattini, P., G. Mura \& V. Ketmaier, 2013. Intra-specific variability in the thirteen known populations of the fairy shrimp Chirocephalus ruffoi (Crustacea: Anostraca): resting egg morphometrics and mitochondrial DNA reveal decoupled patterns of deep divergence. Hydrobiologia 713: 19-34.

Zarattini, P., V. Rossi, B. Mantovani \& G. Mura, 2002. A preliminary study in the use of RAPD markers in detecting genetic differences in hatching patterns of Chirocephalus diaphanus Prévost, 1803 (Crustacea: Anostraca). Hydrobiologia 486: 315-323.

Zarattini, P., V. Rossi \& G. Mura, 2017. Larval identification of two syntopic species Branchipus schaefferi and Tanymastix stagnalis (Crustacea, Anostraca) sheds light on their pattern of coexistence. Hydrobiologia. doi:10.1007/ s10750-017-3302-4. 